\title{
THE EFFECT OF PSYCHOLOGICAL EMPOWERMENT ON MOTIVATION AND PERFORMANCE OF HEALTH CENTER EMPLOYEES IN TOMOHON CITY
}

\author{
Pinaria Marlinda Navratilova Upusna*, Student \\ Supartha Wayan Gede, Sintaasih Desak Ketut, Lecturers \\ Master's Program of Management, Faculty of Economics and Business, \\ University of Udayana, Indonesia \\ *E-mail: upusnavra@hotmail.com
}

\begin{abstract}
Employee performance is the result of work used by modern organizations in order to know the level on their achievement of organizational results in accordance with the vision carried. Data were collected from one hundred and eighty eight (188) respondents who filled up questionnaire. The aim of this research is to determine the effects that psychological empowerment have on the motivation and employees performance among all the workers at all Health center of Tomohon City. The results show that psychological empowerment has significant positive impact on motivation. Therefore, the increased of employees psychological empowerment will enhance higher motivation. Motivation proved to have a positive and significant impact on employee performance, so it can be interpreted that with higher work motivation will encourage the creation of better performance. Empowerment proved to have a positive and significant impact on employee performance, therefore increased psychological empowerment of employees will encourage the improvement of better employee performance. In conclucions, motivation is a good mediator to channel the positive impact that psychological empowerment have on employee performance at all Health center of Tomohon City.
\end{abstract}

\section{KEY WORDS}

Psychological empowerment, motivation, employee, performance.

The development of a country is also determined by the quality of the health of its people as human resources that contribute to the progress of the nation (Irfan and ljaz, 2011). The 1945 Constitution of the Republic of Indonesia in Article $28 \mathrm{H}$ stipulates that health is the basic right of life for every individual and all citizens are entitled to health services. The public health service system is an organization with a complex network and has individuals working together for public health interests (Revere et al., 2011). All aspects of the health service sector are asked to measure their performance and to demonstrate efficiency and effectiveness in order to provide services to their clients (Weir et al., 2009).

Health center are functional organizational units in the field of basic health services that function as (1) health development centers, (2) fostering community participation, (3) comprehensive and integrated health services, which are in line with the concept that health center are responsible for working areas established (Nugroho, 2004). The Health center is a public health service facility that is responsible for the health of the community in its working area (Wibowo, 2009). Basically, quality health services must also be supported by human resources who have quality and performance that supports health care systems that have competitive advantages (Holmes et al., 2006). In order for public health care services in the health center to materialize, nursing services need to be improved. The quality indicators of community nursing services are services performed professionally. Health care professionalism essentially provides services to the community according to standards (Nugroho, 2004).

The service at the hospital, nurses are one of the health professions that play an important role in caring for and serving people who are directly ill. In his daily duties, a nurse is often faced with an attempt to save one's life or life. Regarding the scope of work nurses are always faced with monotonous and routine things. In carrying out their roles and 
functions nurses are required to have high expertise, knowledge and concentration. In addition, a nurse is faced with the demands of professional idealism and often faces various kinds of problems both from patients and colleagues. It can all cause feelings of stress on the nurse, so that it is easy to experience a decrease in motivation in work (Makatiho, 2013).

One form of activity to provide motivation is empowerment efforts. Empowerment means efforts to encourage subordinates to motivate themselves (Ratnawati, 2004). Empowerment of employees is one strategy to realize employees who excel in their performance. Empowerment is one of the development of employees through employee involvement, namely by giving sufficient responsibility to complete tasks and decision making (Kadarisman, 2012). Employees who have felt empowered will have a higher level of work motivation (Rahmasari, 2011). To be able to empower employees in an organization, management must be able to provide access to support the achievement of employee empowerment (Regan, 2011). With empowerment, employees will be able to accommodate customer requests and achieve the highest standards of service quality. Employees are permitted to use their personal initiatives and their judgment in carrying out their duties (Chow et al., 2006).

In addition to empowerment, management of human resources in organizations is that companies must be able to unite perceptions or perspectives of employees and organizational leaders in order to achieve organizational goals, among others through the formation of good mental work with high dedication and loyalty to their work, providing work motivation, guidance, direction and good coordination in working by a leader to subordinates (Brahmasari and Suprayetno, 2008). Motivation has long been the task of management in order to improve employee performance. Motivation will affect the increase in performance, and decrease the level of turnover and absenteeism. Decreasing work morale is a characteristic and lack of motivation felt by most workers (Bangun, 2012). Wayne et al. (1997) in Chow et al. (2006) found that organizational support at a high level creates a sense of obligation, where employees not only feel that they must commit to management, but also feel obliged to repay the favor by putting more effort into their work. When employees feel they part of the organization, employee commitment will develop and their performance increases (Ghafoor et al., 2011).

In the Health Ministry recapitulation data of the Indonesian Ministry of Health, North Sulawesi has 192 health centers spread across 16 regencies and cities. Tomohon City has 7 health centers consisting of 2 non-care health centers and 5 health centers. The Tomohon City Health Center has the task as a District / City health technical implementation unit (UPTD) which is responsible for organizing the health development of the Tomohon area. Tomohon City Health Center as the first stratum health service center conducts first-level health services in a comprehensive, integrated, and sustainable manner, which includes individual health services and public health services. The Tomohon City Health Center conducts activities including public health efforts as a form of health development effort. The study was conducted at seven Tomohon City Health Centers with research areas in all parts of the Health center operations. Based on the results of observations and interviews, several reasons were found which obstacles to the decline in employee performance were. Employees have low work initiatives because of the lack of opportunities for them to work independently. In addition, employees have less motivation because they choose to work alone and feel they are on a team that cannot provide support and assistance. There are still employees of the Tomohon City Health Center who arrive late and do not comply with the stipulated time rules which can trigger a decrease in the performance of employees and organizations if there is no follow-up from the agency.

This study aims to analyze (1) the effect of psychological empowerment on motivation; (2) the influence of motivation on employee performance; (3) the effect of psychological empowerment on employee performance. 


\section{LITERATURE REVIEW}

Performance is a condition that must be known and informed to certain parties to find out the level of achievement of the results of an agency associated with the vision carried out by an organization and knowing the positive and negative impacts of an operational policy taken (Chasanah, 2008). Empowerment is one way of developing employees through employee involvement, namely by giving sufficient responsibility to complete tasks and decision making (Kadarisman, 2012). Empowerment can be viewed from two perspectives namely structural perspective and psychological perspective (Mario, 2010). Viewed from an organizational (structural) point of view, empowerment is the process of encouraging employees to set the goals of their work, and to provide greater capacity, responsibility, or authority to make decisions within the scope of their own work aimed at increasing engagement (Job Involvement) and employee job satisfaction to improve the quality of production and service (Mario, 2010). Viewed from the point of view of human resources (psychological), empowerment is the giving of opportunities and encouragement to employees to utilize their talents, skills, resources, and experience to complete work in a timely manner or in other words as feeling meaningful, capable, control their own work and have an important impact on society (Mario, 2010). Mathis and Jackson (2006) say, motivation is a desire in someone causing the person to do something. Someone takes action for something to achieve the goal. Motivation can be defined as an action to influence other people to behave regularly.

\section{RESEARCH HYPOTHESES}

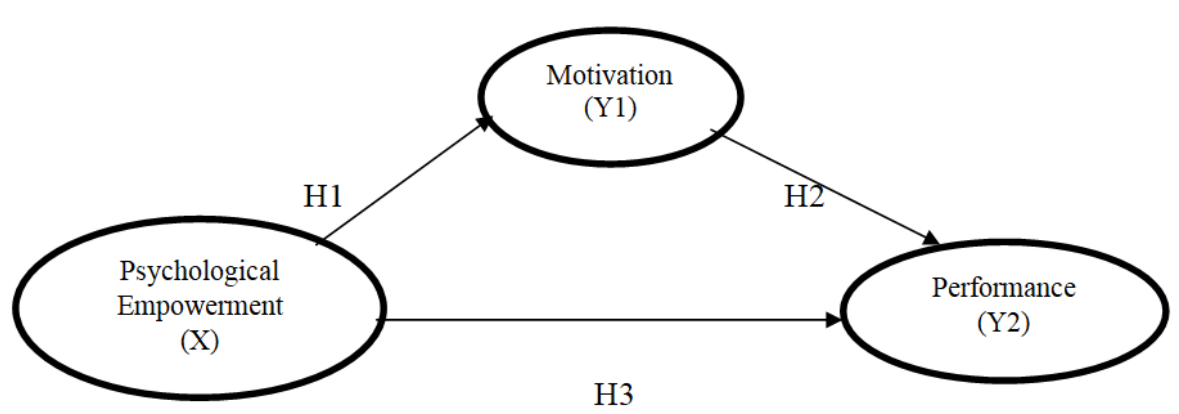

Figure 1 - Research Framework (Source: concept developed in this study, 2015)

H1: Psychological Empowerment has a positive and significant influence on motivation; H2: Motivation has a positive and significant influence on employee performance; performance.

H3: Psychological Empowerment has a positive and significant influence on employee

\section{METHODS OF RESEARCH}

Based on the problems studied, this study belongs to associative research (relationship), namely the causal relationship between variables of psychological empowerment, motivation and employee performance. This research was conducted at the Health center in the administrative area of Tomohon City. The reason behind the researchers conducting research at the Tomohon City Health Center is that this organization is a public service organization that is relied on by the community, both at the City and Village levels and is one proof of government work that can be directly felt by the community. Health center are expected to be able to provide quality and professional services. For this reason, it is necessary to empower psychological staff to achieve goals effectively. This study uses employee motivation and employee performance as organizational supporting factors in improving ability to achieve the highest standards of service quality. The object of research in this study is psychological empowerment, motivation and employee performance. The 
method of data collection in this study was conducted with several data collection techniques, namely, interviews, questionnaires, observations and literature. The analysis techniques used were confirmatory factor analysis and path analysis. The population used for this study was 366 people in all the Health center staff in Tomohon City, North Sulawesi Province.

In this study used the proportionate stratified random sampling technique using formulas from Isaac and Michael in, Sugiyono (2013: 158). Based on the formula in with a population of 366 people and precision of $5 \%$, it is calculated as 188 .

The number of samples is obtained based on the location of the Health center which can be seen in Table 1. The number of samples based on the department obtained will be searched randomly at the employees of each Health center unit in Tomohon City.

Table 1 - The composition of the Health center sample in the city of Tomohon based on the location of the health center

\begin{tabular}{llll}
\hline No & Health center & Total population & Sample \\
\hline 1. & Pangolombian & 50 & 26 \\
\hline 2. & Lansot & 55 & 28 \\
\hline 3. & Matani & 55 & 28 \\
\hline 4. & Rurukan & 45 & 23 \\
\hline 5. & Tara-tara & 61 & 32 \\
\hline 6. & Tinoor & 45 & 23 \\
\hline 7. & Kakaskasen & 55 & 28 \\
\hline & Total & & 188 \\
\hline
\end{tabular}

Source: Data Processed, 2015.

The population consisting of 366 employees with a sample of 188 employees can be grouped based on the type of position or profession, namely Doctors, Dentists, Nurses, Dental Nurses, Midwives, Pharmacists, Pharmacist Assistants, Physiotherapists, Nutritionists, Sanitarians, Extension and Administration who can see in Table 2 below.

Table 2 - The composition of the Health center sample in the city of Tomohon is based on the position of the health center staff

\begin{tabular}{llll}
\hline No & Position & Total population & Sample \\
\hline 1. & Doctor & 29 & 18 \\
\hline 2. & Nurse & 190 & 93 \\
\hline 3. & Dentist & 19 & 8 \\
\hline 4. & Midwife & 44 & 23 \\
\hline 5. & Pharmacist & 19 & 8 \\
\hline 6. & pharmacist assistant & 10 & 5 \\
\hline 7. & Physiotherapist & 11 & 6 \\
\hline 8. & Nutritionist & 10 & 5 \\
\hline 9. & Sanitarian & 13 & 8 \\
\hline 10. & Extension & 12 & 7 \\
\hline 11. & Administration & 12 & 7 \\
\hline & Total & & 188 \\
\hline
\end{tabular}

Source: Data Processed, 2015.

\section{RESULTS OF STUDY}

Confirmatory factor analysis is used to test whether the indicators used are really indicators of a variable. The confirmatory factor analysis stages are as follows.

Bartlett's Test Value Test has a significance value less than the real level $(\mathrm{sig}<0.05)$. The results of the analysis can be seen in Table 3.

Table 3 shows that the Chi-square value for each variable has a significance value below 0.05 , so this means that each item in the instrument has a strong correlation value so that it is feasible to be used in factor analysis. 
Table 3 - Correlation Coefficient of Variable Matrix

\begin{tabular}{llll}
\hline No & Variable & Chi-square & Sig \\
\hline 1 & Empowerment & 238,097 & 0,000 \\
2 & Motivation & 658,614 & 0,000 \\
3 & Performance & 369,629 & 0,000 \\
\hline
\end{tabular}

Source: Data Processed, 2015.

Factor analysis is said to be feasible if the $\mathrm{KMO}$ amount is at least 0.5 . The results in this study can be seen in Table 4.

Table 4 - Kaiser Mayer Olkin Test (KMO)

\begin{tabular}{llll}
\hline No & Variable & KMO & Ket. \\
\hline 1 & Empowerment & 0,717 & Valid \\
2 & Motivation & 0,897 & Valid \\
3 & Performance & 0,840 & Valid \\
\hline
\end{tabular}

Source: Data Processed, 2015.

Table 4 shows that Kaiser Mayer Olkin (KMO) value for each variable is greater than 0.5. This means that each variable has sufficient sample to carry out factor analysis.

The MSA value of each variable must be greater than 0.5 . The results of the analysis can be seen in Table 5 . Table 5 shows the value of MSA for each variable indicator has a value greater than 0.5 , so this means that the model used is feasible to be used in the factor analysis model.

Table 5 - Analysis Measure of Sampling Adequacy (MSA)

\begin{tabular}{llll}
\hline No & Variable & Question Items & MSA Value \\
\hline 1 & Psycological Empowerment $(\mathrm{X})$ & $\mathrm{X} 1$ & 0,701 \\
& & $\mathrm{X} 2$ & 0,707 \\
& & $\mathrm{X} 3$ & 0,729 \\
2 & $\mathrm{X} 4$ & 0,730 \\
& Motivation $\left(\mathrm{Y}_{1}\right)$ & $\mathrm{Y} 1.1$ & 0,875 \\
& & $\mathrm{Y} 1.2$ & 0,896 \\
& $\mathrm{Y} 1.3$ & 0,900 \\
& & $\mathrm{Y} 1.4$ & 0,892 \\
& & $\mathrm{Y} 1.6$ & 0,930 \\
& & $\mathrm{Y} 1.7$ & 0,889 \\
3 & Performance $(\mathrm{Y} 2)$ & $\mathrm{Y} 2.1$ & 0,897 \\
& & $\mathrm{Y} 2.2$ & 0,840 \\
& & $\mathrm{Y} 2.3$ & 0,834 \\
& & $\mathrm{Y} 2.5$ & 0,862 \\
& & & 0,862 \\
& & 0,3 & \\
\hline
\end{tabular}

Source: Data Processed, 2015.

Determination of the number of factors is determined based on factors that have an eigenvalue greater than / equal to 1. This is based on the percentage of variance of a factor that is considered by the customer if it has a value greater than 60 percent.

Table 6 - Eigen Value

\begin{tabular}{llll}
\hline No & Variable & Eigen Value & Cumulative Variance (persent) \\
\hline 1 & Psycological Empowerment & 2,458 & 61,441 \\
2 & Motivation & 4,305 & 61,501 \\
3 & Performance & 3,128 & 62,556 \\
\hline
\end{tabular}

Source: Data Processed, 2015.

Table 6 shows that the eigen value of each variable is greater than 1 , and the percentage of variance value is greater than 5 percent, this means that each variable, 
psychological empowerment $(\mathrm{X})$ and motivation $(\mathrm{Y} 1)$ is a variable that affects performance (Y2), so it is feasible to be used in the model.

The loading factor of the dependent variable in this study is work motivation (Y1) which has seven indicators and employee performance (Y2) which consists of five indicators, and the independent variable $(x)$ which is psychological empowerment which has four indicators. The results of loading factors can be seen in Table 7 .

Table 7 - Value of Factor Loading

\begin{tabular}{lllll}
\hline No & Variable & Indicators & Factor Loading & Information \\
\hline 1 & Psycological Empowerment $(\mathrm{X})$ & $\mathrm{X} 1$ & 0,716 & Valid \\
& & $\mathrm{X} 2$ & 0,841 & Valid \\
& & $\mathrm{X} 3$ & 0,794 & Valid \\
& & $\mathrm{X} 4$ & 0,780 & Valid \\
& Motivation (Y1) & $\mathrm{Y} 1.1$ & 0,739 & Valid \\
& & $\mathrm{Y} 1.2$ & 0,765 & Valid \\
& $\mathrm{Y} 1.3$ & 0,800 & Valid \\
& & $\mathrm{Y} 1.4$ & 0,816 & Valid \\
& & $\mathrm{Y} 1.5$ & 0,803 & Valid \\
& & $\mathrm{Y} 1.6$ & 0,776 & Valid \\
& Performance (Y2) & $\mathrm{Y} 1.7$ & 0,787 & Valid \\
& & $\mathrm{Y} 2.1$ & 0,743 & Valid \\
& & $\mathrm{Y} 2.2$ & 0,827 & Valid \\
& $\mathrm{Y} 2.3$ & 0,772 & Valid \\
& $\mathrm{Y} 2.4$ & 0,789 & Valid \\
\hline
\end{tabular}

Source: Data processed, 2015.

Table 7 shows that the value of loading indicator variables for psychological empowerment $(\mathrm{X})$, work motivation $(\mathrm{Y} 1)$ and employee performance $(\mathrm{Y} 2)$ is greater than 0.4 . This means that all indicators of each variable meet the requirements and show a strong correlation.

From the formed path model, there are two structural equations or simultaneous equation systems. Forms of structural equations for the Path Analysis model used are:

Structural Equations 1: Motivation $=\beta 1$ Psycological Empowerment $+\mathrm{e} 1$

Structural Equations 2: Performance $=\beta 2$ Motivation $+\beta 3$ Psycological Empowerment $+\mathrm{e} 2$

From the results of data processing with SPSS, the structural equation model or the system of simultaneous equations for the first structure and the second structure includes the results of direct effect testing and testing of mediating variables, showing results as in Tables 8 and Table 9.

Table 8 - Recapitulation of Structure Regression Results 1

\begin{tabular}{|c|c|c|c|c|c|}
\hline \multirow{2}{*}{ Model } & \multicolumn{2}{|c|}{ Unstandardized Coefficients } & \multirow{2}{*}{$\begin{array}{l}\text { Standardized Coefficients } \\
\text { Beta }\end{array}$} & \multirow[b]{2}{*}{$\mathrm{T}$} & \multirow{2}{*}{ Sig. } \\
\hline & Beta & Std. Erorr & & & \\
\hline (Constant) & 1.194 & 0.205 & 0.695 & 5.814 & 0,000 \\
\hline $\begin{array}{l}\text { PD } \\
\mathrm{R}^{2}: 0,483 \\
\text { F Statistik: } \\
\text { Sig.F: } 0,00\end{array}$ & $\begin{array}{l}0.677 \\
076\end{array}$ & 0.051 & & 13.194 & 0.000 \\
\hline
\end{tabular}

a. Dependent Variable: Motivation.

Source: Data Processed, 2015.

Based on the results of the regression analysis in Table 8 it was found that Psychological Empowerment had a positive and significant effect on Motivation. This is indicated by a significant test of the Psychological Empowerment variable of 0.000 which is smaller than 0.05 . The magnitude of the variable path coefficient of Psychological 
Empowerment is 0.695 which means that the contribution of Psychological Empowerment to Motivation is $69.5 \%$.

The error value of this structural model 1 can be calculated using the formula:

$$
\mathrm{Pe}_{1}=\sqrt{\left(1-R_{1}^{2}\right)}=0,719
$$

The error value of 0.719 means that the motivation variant is $71.9 \%$ determined by variables outside the model (variable Psychological Empowerment).

Table 9 - Recapitulation of Structure Regression Results 2

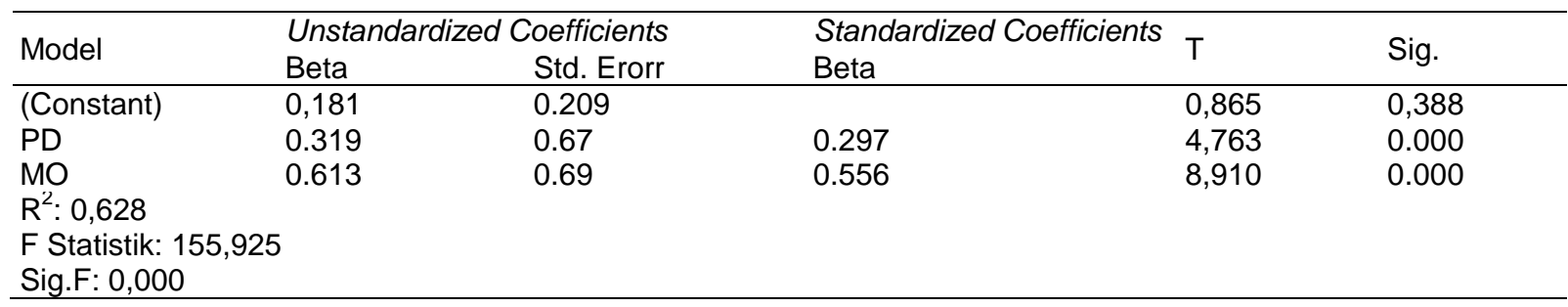

a. Dependent Variable: Performance.

Source: Data Processed, 2015.

Based on the results of the regression analysis in Table 9, it was found that Psychological Empowerment and Motivation had a significant positive effect on Employee Performance. This is indicated by the significance of the $t$ test of the Psychological Empowerment variable of 0.000 and the significance of the test of the Motivation variable of 0.000 which is smaller than 0.05. The magnitude of the variable path coefficient of Psychological Empowerment is 0.297 , which means that the contribution of Psychological Empowerment to employee performance is $29.7 \%$. The magnitude of the path coefficient of the Motivation variable on employee performance is 0.556 , which means that the contribution of motivation to employee performance is $55.6 \%$. This indicates that the high and low performance of $55 \%$ is determined by motivation. The error value of this structural model 2 can be calculated by the formula:

$$
\mathrm{Pe}_{2}=\sqrt{\left(1-R_{i}^{2}\right)}=0,609
$$

The error value of 0.609 means that the variant of Employee Performance $60.9 \%$ is determined by variables outside the model (outside the variables of Psychological Empowerment and Motivation).

Data analysis to test the hypothesis about the effect of Psychological Empowerment on using structural equations without mediation. The results of data analysis to examine the effect of the variable Psychological Empowerment on Employee Performance are presented in Table 10.

\begin{tabular}{|c|c|c|c|c|c|}
\hline Model & \multicolumn{2}{|c|}{ Unstandardized Coefficients } & $\begin{array}{l}\text { Standardized Coefficients } \\
\text { Beta }\end{array}$ & $\mathrm{T}$ & Sig. \\
\hline $\begin{array}{l}\text { (Constant) } \\
\text { PD }\end{array}$ & $\begin{array}{l}0.913 \\
0.734\end{array}$ & $\begin{array}{l}0.230 \\
0.057\end{array}$ & 0.684 & $\begin{array}{l}3.975 \\
12.788\end{array}$ & $\begin{array}{l}0.000 \\
0.000\end{array}$ \\
\hline $\begin{array}{l}\mathrm{R}^{2}: 0,468 \\
\mathrm{~F} \text { Statistik: } \\
\text { Sig.F: } 0,00\end{array}$ & & & & & \\
\hline
\end{tabular}

Table 10 - Recapitulation of Results of Regression without Mediation

a. Dependent Variable: Performance.

Source: Data Processed, 2015. 
Based on the results of the regression analysis in Table 10, it was found that Psychological Empowerment had a positive and significant effect on Performance. This is indicated by a significant test of the Psychological Empowerment variable of 0.000 which is smaller than 0.05. The magnitude of the variable path coefficient of Psychological Empowerment is 0.684 , which means that the contribution of Psychological Empowerment to Motivation is $68.4 \%$.

The error value of this structural model 3 can be calculated with formulation:

$$
\mathrm{Pe}_{3}=\sqrt{\left(1-R_{1}^{2}\right)}=0,729
$$

An error value of 0.729 means that the performance variant of $72.9 \%$ is determined by variables outside the model (variable Psychological Empowerment).

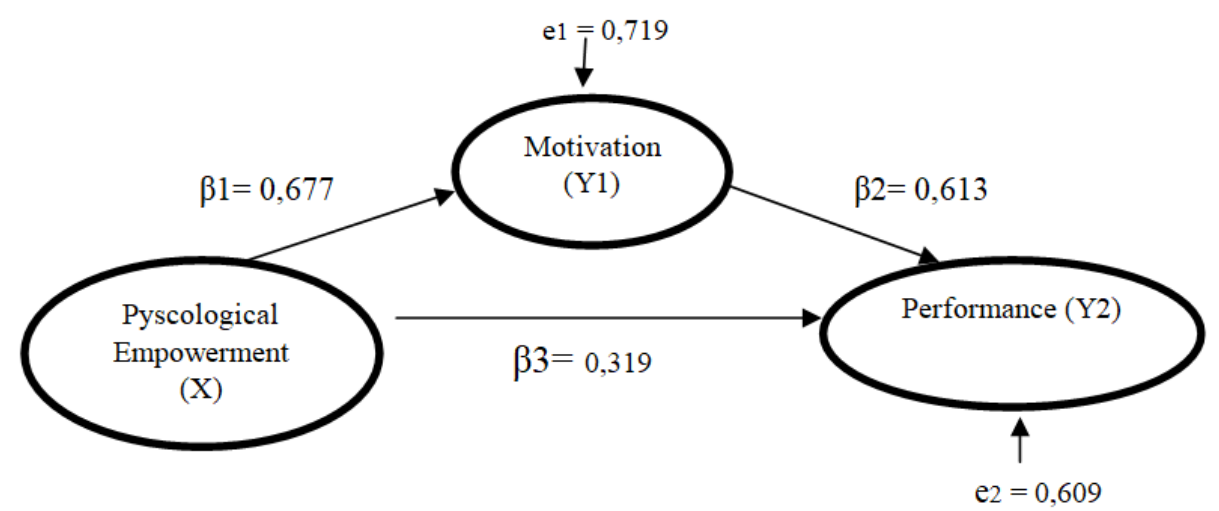

Figure 2 - Final Path Chart Model

After knowing the value of the path coefficient and standard error, it can be calculated the indirect effect and total effect of the variable psychological empowerment on the performance of employees in the Tomohon City Health Center. From the calculation results obtained the following results:

- From the calculation of the indirect effect of psychological empowerment on employee performance through Motivation $(\beta 1 \times \beta 2)=(0.677 \times 0.613)$ in the Tomohon City Health Center it was obtained 0.386 which means that indirect influence of psychological empowerment on performance through motivation in Tomohon City Health Center was 0.386 or $38.6 \%$;

- From the calculation of the total effect on the performance of Tomohon City Health Center employees $(\beta 3+\beta 1 \times \beta 2)=(0.319+0.677 \times 0.613)$ the results are 0.683 . The result of 0.683 means that the influence of psychological empowerment and motivation variables on employee performance in Tomohon City Health Center is 0.683 or $68.3 \%$.

The goodness of fit test can be seen from the goodness of fit structural model in the path analysis in the form of the Total Determination Coefficient (R2m), which is calculated based on the R2 value of each endogenous variable. The model is said to be fit if supported by empirical data. By paying attention to the results of path analysis as presented in Table 5.12 and Table 5.13, it is known for the motivation variable (Y1), the value of $R 2=0.483$ and for the performance variable (Y2) obtained $\mathrm{R} 2=0.628$.

$$
R_{m}^{2}=1-\left(P e_{1}\right)^{2}\left(P e_{2}\right)^{2}=0,81
$$

The total determination value of 0.81 means that $81 \%$ of empirical data can explain the model or the model is said to be good. Thus, the model is feasible to provide an explanation and testing of the hypothesis.

To test the significance of the mediating role of the motivational variable, the Sobel formula is used. The results are obtained as follows: 
Ho: Motivation is stated not to mediate the relationship between Psychological Empowerment and Employee Performance.

$\mathrm{H}_{1}$ : Motivation is stated to mediate the relationship between Psychological Empowerment and Employee Performance.

Based on the path diagram of indirect influence, it can be calculated The standard error coefficients $a$ and $b$ are written with $\mathrm{Sa}$ and $\mathrm{Sb}$, the standard size of indirect effect $\mathrm{Sab}$ is calculated by the following formula:

$$
\mathrm{S}_{\mathrm{ab}}=\sqrt{b^{2} S_{a}^{2}+a^{2} S_{b}^{2}+S_{a}^{2} S_{b}^{2}} \mathrm{~S}_{\mathrm{ab}}=0,0558
$$

To test the significance of the indirect effect it is necessary to calculate the $z$ value of the ab coefficient, and the value is 6,92 .

From the calculation results, the ratio of $z$ count is $6.92>z$ table is 1.96 , then Ho is rejected and $\mathrm{Hi}$ is accepted. This means that motivation mediates the relationship of psychological empowerment to employee performance at the Tomohon Health Center, so that it can be said that motivation is a mediating variable the influence of empowerment on employee performance. The determination coefficient for the regression equation with the mediating variable is $55.6 \%$, which means that the vairation that occurs on employee performance is caused by psychological empowerment through motivation of $55.6 \%$, while the remaining $44.4 \%$ is due to other variables not analyzed, while the results of coefficient of determination for the regression equation without mediation variables obtained at $68.4 \%$.

\section{DISCUSSION OF RESULTS}

Effect of Psychological Empowerment on Motivation. The first hypothesis is the hypothesis which states that Psychological Empowerment has a positive and significant influence on Motivation. Psychological Empowerment $(X)$ is proven to have a positive and significant effect on motivation (Y1), which is indicated by the path coefficient value of 0.677 , with a significance level or $p$-value $=0,000$, which means very significant.

In this study found a positive and significant influence between psychological empowerment and motivation. The path coefficient has a positive sign, it can be interpreted that the increasing implementation of psychological empowerment of employees will be able to encourage the creation of higher work motivation. This shows that psychological empowerment measured by indicators: meaning, competence, self determination and impacts can increase the motivation of employees in the Tomohon City Health Center to be greater. This can be interpreted that if the employee gives the best effort at work, has the confidence in the ability to work, is responsible for the work and believes that the work done will have an impact on the agency, thus making these employees tend to have higher motivation so that they feel comfortable and motivated in carrying out their work. Thus, then hypothesis 1 that reads, psychological empowerment has a positive and significant effect on motivation, supported.

Effect of Motivation on Employee Performance. The second hypothesis states that Motivation has a positive and significant influence on Employee Performance. Motivation (Y1) is proven to have a positive and significant effect on performance (Y2), which is indicated by the path coefficient value of 0.613 , with a significance level or $p$-value $=0,000$, which means it is very significant.

In this study found a path coefficient marked positive, it can be interpreted that increasing employee motivation will be able to encourage the creation of better performance. This shows that employee motivation as measured by indicators: reward systems, salary, interpersonal relations, responsibility, knowledge / training and information can improve the performance of Tomohon City Health Center employees to be higher. This can be interpreted that if the employee gets enough rest time, receives overtime fees, has a good relationship with his boss and coworkers, is able to operate the tool, has the opportunity to communicate ideas about work and has the knowledge needed to do work assignments, thus being able to improve better performance at Tomohon City Health Center employees. Thus, then 
hypothesis 2 that reads, motivation has a positive and significant effect on performance, supported.

The Effect of Psychological Empowerment on Employee Performance. The third hypothesis states that Psychological Empowerment has a positive and significant influence on Employee Performance. Psychological Empowerment (X) proved to have a positive and significant effect on performance (Y2), which is indicated by the path coefficient value of 0.319 , with a significance level or $p$-value $=0,000$, which means it is very significant.

In this study it was found that the path coefficients were positively marked, meaning that increasing the implementation of psychological empowerment of employees would be able to encourage better performance. This shows that psychological empowerment is measured by indicators: meaning, competence, self-determination and impacts can improve the performance of Tomohon City Health Center employees to be higher. This can be interpreted if the employee feels the work done is very meaningful, always wants to give the best for the agency, has the ability to do work in detail, has the opportunity to work independently, has confidence in dealing with patients, thus the employee of Tomohon City Health Center is able improve their performance for the better. Thus, hypothesis 3 which reads, empowerment has a positive and significant effect on acceptable performance.

Research Limitations:

Research only uses path analysis analysis techniques, which should be able to be further developed with other analysis techniques, such as: PLS, confirmatory and SEM analysis, multiple linear regression and AMOS.

Research uses only one independent variable, Psychological Empowerment, which should be developed again by adding other independent variables such as Structural Empowerment. Research uses only one independent variable, Psychological Empowerment, which should be developed again by adding other independent variables such as Structural Empowerment.

\section{CONCLUSION AND SUGESSTIONS}

Psychological empowerment has a positive and significant influence on motivation, meaning that the greater the application of empowerment to employees will have an impact on the increasing motivation of employees in the Tomohon City Health Center.

Motivation has a positive and significant influence on employee performance, meaning that the higher the motivation to work for employees will have an impact on increasing employee performance in the Tomohon City Health Center.

Psychological empowerment has a positive and significant influence on employee performance, meaning that the greater the application of empowerment to employees will have an impact on increasing employee performance at the Tomohon City Health Center.

Employee motivation is able to mediate a positive relationship of psychological empowerment to employee performance, meaning that high work motivation has a positive role in increasing psychological empowerment for employees so that it can produce high employee performance.

Based on the conclusions above, the suggestions given are as follows.

The head of the Tomohon City Health Center must improve the empowerment of employees, for example, provide more opportunities for employees to take part in decision making and work independently so that they can take more initiative and be more responsible in their work.

The leadership of the Tomohon City Health Center considers the policy of overtime or allowance costs for employees who have a workload that exceeds the rules of the Health center such as when they have to work during holidays or work outside the service area.

The leadership must encourage employees to comply with the activity schedule at the Tomohon City Health Center as well as work time rules so that no more employees arrive late or have to work beyond the specified working hours.

For further research, it is recommended that using analytical techniques that are more able to develop research results in this case using PLS analysis. 


\section{REFERENCES}

1. Brahmasari, Ida Ayu dan Agus Suprayetno. 2008. Pengaruh motivasi kerja, kepemimpinan, dan budaya organisasi terhadap kepuasan karyawan serta dampaknya pada kinerja perusahaan (studi kasus pada PT. Pei Hai International Wiratama Indonesia). Jurnal Manajemen dan Kewirausahaan, Vol 10. pp. 124135.

2. Chasanah, N. 2008. Analisis Pengaruh Empowerment, Self Efficacy dan Budaya Organisasi Terhadap Kepuasan Kerja Dalam Meningkatkan Kinerja Karyawan (Studi Empiris pada Karyawan PT.Mayora Tbk Regional Jateng dan DIY). Tesis. Program Magister Manajemen Univeristas Diponegoro Semarang.

3. Chow, Irene H., Lo, Thamis W., Sha, Zhenquan, and Hong, Jiehua. 2006. The impact of developmental experience, empowerment, and organizational support on catering service staff performance. International Journal of Hospitality Management, Vol 25, pp. 478495

4. Ghafoor, A., Qureshi, T.M., Khan and Hijazi 2011. Transformational leadership, employee engagement and performance: mediating effect of psychological ownership. African Journal of Business Management, Vol 5, No 17, pp. 73917403.

5. Holmes, J.S., Gutierrez de Pineres, S.A., and Kiel, D.L. 2006. Reforming government agencies internationally: Is there a role for the Balanced Scorecard?. School of Social Sciences, pp. 128

6. Irfan, S.M., Ijaz, A. 2011. Comparison of service quality between private and public hospitals: empirical evidences from Pakistan. Journal of Quality and Technology Management, Vol VII, Iss 1, pp. 122.

7. Jackson, E.S., Schuler, S.R., \& Werner, S.2011. Pengelolaan Sumber Daya Manusia. Jakarta: Salemba Empat.

8. Kadarisman, M. 2012. Manajemen Pengembangan Sumber Daya Manusia. Jakarta: PT. RajaGrafindo Persada.

9. Mario, R.H. 2010. Analisis pengaruh pemberdayaan structural dan pemberdayaan psikologis terhadap kepuasan kerja dan komitmen organisasi (Studi kasus di PT. X Jakarta). Sekolah Pascasarjana Institut Pertanian Bogor. Bogor.

10. Mathis, R.L and Jackson, J.H. Manajemen Sumber Daya Manusia. Jakarta: Salemba Empat.

11. Rahmasari, L. 2011. Peningkatan Motivasi Melalui Pemberdayaan Psikologis dan Dampaknya Terhadap Kinerja Karyawan. Majalah IImiah Informatika, Vol 2, No 1, pp. 5767.

12. Regan, Loretta .C \& Rodriguez Lori. 2011. Nurse empowerment from a middlemanagement perspective: nurse managers' and assistant nurse manager's workplace empowerment views. The Permanente Journal, Vol 15, pp. e 101- e 107.

13. Revere, D., Nelson, K., Thiede, H., Duchin, J., Stergachis, A., and Baseman, J. Public health emergency preparedness and response communications with health care providers: a literature review. BMC Public Health, Vol 11, pp.337.

14. Thomas, K.W. and Velthouse, B.A. 1990. Cognitive elements of empowerment. Academy of Management Review, Vol 15, No 4, pp. 666681.

15. Wayne, S.J., Shore, L.M., \& Linden, R.C. 1997. Perceived organizational support and leader-member exchange: a social exchange perspective. Academy of Management Journal, Vol 40. pp. 82111.

16. Weir, E., d'Entremont, N., Stalker, S., Kurji, K., and Robinson, V. 2009. Applying the balanced scorecard to local public health performance measurement: deliberations and decisions. BMC Public Health, Vol 9, pp. 127.

17. Wibowo, H.T. 2009. Mengukur kinerja pelayanan kesehatan di Health center menggunakan instrument kualitas berorientasi pelanggan di Kabupaten Aceh Tenggara. Buletin Penelitian Sistem Kesehatan, Vol 12, No 4, pp. 370377. 